\title{
The Swedish comprehensive school-lost in transition?
}

\author{
Ingrid Carlgren
}

\begin{abstract}
The Swedish comprehensive school system was developed from 1950 to 1971. In the 1990s the system was radically restructured. Developments were based on consensus between different political parties up until the 1980 s, however after this date the debate has become more polarised. In 2006 an alliance of four parties was elected to government and began to realise a 'new educational policies'. As in many other countries, the results of PISA and other international comparative tests are used to 'scandalise' the existing educational system in order to accelerate the introduction of change. However, it is not the under-achieving restructured school which is scandalised but the ideas and ideals of the previous, not under-achieving, comprehensive school system. In this article the development of the Swedish school model, as well as its changes during the 1990s and thereafter, are described - against the background of the Swedish welfare model and alterations to it.
\end{abstract}

Keywords: Comprehensive school system in Sweden - Educational policies in Sweden · Restructuring of education in Sweden $\cdot$ Sweden

\section{Die schwedische Gesamtschule - verloren in Transitionen?}

Zusammenfassung: Das schwedische Gesamtschulsystem ist in der Zeit von 1950 bis 1971 entwickelt worden. In den 1990er-Jahren wurde es radikal restrukturiert. Die Entwicklung basierte auf einem Konsens verschiedener politischer Parteien bis in the 1980er-Jahre, danach hat sich allerdings die Debatte polarisiert. Im Jahre 2006 kam eine Allianz von vier Parteien an die Macht und begann damit, eine ,neue Politik der Erziehung' zu realisieren. Wie in vielen anderen Ländern auch werden die Ergebnisse in PISA und anderen international vergleichenden Tests benutzt, um das existierende Bildungssystem zu ,skandalisieren' und so die Einführung von Veränderungen zu beschleunigen. Allerdings wird nicht die restrukturierte Schule, die nicht die gewünschten Leistungen erbringt, skandalisiert, sondern die Ideen und Ideale des vorangegangenen Gesamtschulsystems, das keineswegs hinter den Erwartungen zurückgeblieben ist. In diesem Beitrag werden die Entwicklung des schwedischen Schulmodells und dessen Veränderungen seit den 1990er-Jahren beschrieben - auf der Folie des schwedischen Wohlfahrtsstaatsmodells und seiner Veränderungen.

Published online: 02.02 .2010

(C) Die Autor(en) 2010. Dieser Artikel ist auf Springerlink.com mit Open Access verfügbar.

Prof. Dr. I. Carlgren $(\bowtie)$

Faculty of Social Sciences, Stockholm University, Konradsbergsgatan 24 A

10691 Stockholm, Sweden

e-mail: Ingrid.Carlgren@inca.su.se 
Schlüsselwörter: Gesamtschulsystem in Schweden · Bildungspolitik in Schweden .

Schulreform in Schweden Schweden

In the twentieth century, comprehensive school systems, linked to each other, were developed and expanded in all the Nordic countries. A comprehensive school system in Nordic terms refers to a unified, unstreamed school system where all pupils, despite academic and economic backgrounds and resources, are enrolled in the same age-based school. The Swedish comprehensive school system was developed from 1950 to 1971. In the 1990s the system was radically restructured and since 2006 the government, led by the conservative party, has launched a number of reforms which, in several ways, imply a redifferentiation of the school system.

The use of international studies and league tables to accelerate change in local educational systems is widespread (Steiner-Khamsi 2003), and Sweden is no exception. The present government reforms are legitimised by what Steiner-Khamsi calls "scandalization" of the previous school system. In contrast to the German debate about the need to reconsider the highly selective educational structure, the current Swedish debate is about the need to create a more selective system and to restore the traditional school characterised by 'peace and quiet' as well as knowledge acquisition. This may seem paradoxical, but analysis of the international league tables show, on the one hand, that comprehensive school systems seem to be one important factor in keeping the general achievement level high. At the same time, it seems to be the more traditional school systems (in terms of curricular construction, teacher roles and teaching methods) that produce better achievements (Donnelly 2005).

Although there are great similarities between the Nordic countries, as welfare societies as well as between their school systems, there are more differences than commonly believed. The Nordic situation offers interesting variations within the framework of a comprehensive school system.

The focus in this article will be on the Swedish comprehensive school system, as well as on recent changes to the system. After almost 50 years of striving towards integration-of different school forms, educational programs, social groups, ability groups etc.- - a growing differentiation within the framework of the comprehensive school has begun. To contextualise the emergence of the Swedish school system as well as its changes, I will start with a description of the Swedish welfare model and the rise and fall of the strong state. The accomplishments of comprehensive school reforms depended, to a large extent, on the strong Swedish state and the restructuring reforms during the 1990 s were parallel to the decline of the strong state.

\section{The Swedish model}

The Swedish Welfare Model has been called "the most ambitious and publicised integration of a modern developed economy with an active welfare state and complementary social institutions." (Freeman et al. 2006, p. 2) It has appeared as extremely successful in that it allowed Sweden to maintain full employment for a prolonged period while at the same time it eliminated poverty and compressed the differentiation of wages and income. 
It is a mixed model of universal and work-related welfare (Lindbom and Rothstein 2004) which was historically based on collaboration between the state and the organisations representing labour and capital. A number of welfare reforms, including the major educational reforms of the post-war period, were based on concepts of centralism, universality and consensus (Lindblad and Lundahl 1999). The situation in Sweden after World War II was unique - firstly the historical agreement in Sweden between capital and labour (both in taking responsibility for societal development) and secondly a country that had remained outside the war and consequently had retained an intact social structure including well-organised industry. These were prerequisites for the strong, post-war economic growth which formed the basis of social reforms and the development of the probably most expansive welfare system in the world.

The Nordic countries, and especially Sweden, perceived themselves as in the vanguard of social progress. The politics of compromise formed 'the middle way', and the image of general progressiveness made Sweden the prototype of modern society. In the early fifties the concept of the Swedish model had embedded itself in the nation's domestic political rhetoric.

The following quote from the Danish writer Henrik Stangerup in a Danish newspaper article from 1965 is an example of how the myths of the Scandinavian welfare societies were, to a large extent, generated from the inside:

Today in Scandinavia we are experiencing one of the most important experiments in world history. That may sound pretentious, yet it isn't. Scandinavia of today is the world's avant-garde society. What is taking place among us today will happen in other countries tomorrow, as soon as they have reached a comparable level of freedom and welfare. (Ruth 1984, p. 63)

The economic situation changed as early as the 1970s which, however, did not stop the expansive state from continuing its costly reforms. In the 1980s the Nordic countries had reached a situation in which it was impossible to raise taxes any further. In Sweden new social reforms came to an end and public opinion was polarised with growing criticism of the welfare model (such as complaints about its costs, high taxes, Sweden's aid to developing countries, as well as general criticism of bureaucracy and technocracy). The concept of progress changed its meaning, too. The case of Sweden thus takes on a new political significance in the changing ideological climate of the 1980s. The image of Sweden evolved into one "where the fears of, rather than the hopes for, modernity are projected" (Ruth 1984, p. 58).

From 1992 to 1995 Sweden experienced an economic crisis. At that time the budget deficit was more than $12 \%$, government was spending more than $70 \%$ of GDP. Approximately $14 \%$ of the population was without a job (which had not happened since the Great Depression of the 1930s). Sweden's position in real income per capita had dropped from near the top of OECD countries almost to the bottom (Freeman et al. 2006, p. 2). Only in the early 1990s did policy makers give low inflation priority over full employment.

The crisis of the 1990s accelerated reforms of Swedish social policies and institutions. Economic advisors identified two main problems: the small Swedish market for private services and the high minimum wages (which because of the immigration of lower-skilled workers became an increasing problem). 
The Swedish model has, however, survived and today even the new conservatives are in favour of the welfare state. However it is a somewhat different welfare model. It has changed to a less universal and more work-related type of welfare state and towards lower levels of generosity. It is "becoming more suited to the needs of the middle class than to the new working class consisting largely of immigrants and people with part-time jobs" (Lindbom and Rothstein 2004, p. 4).

During the period 1995 to 2004, productivity in Sweden grew more than the OECD average. However, it was not followed by comparable job creation (in contrast to other countries) which has strengthened the focus on the need for private service sector growth. According to economists, globalisation is a challenge to the ambitions of the Swedish welfare state since it requires increased income differences. A wage distribution pattern that is compressed for egalitarian reasons is deviating more and more from market realities. Neo-liberal ideology has, to a large extent, penetrated problem identification as well as solutions - at least up until the current financial crisis.

\subsection{The rise and fall of the strong state}

One prominent aspect of the Swedish welfare model has been a strong state and a rationalistic model of social governance. Social change was seen to be accomplished through a political and administrative process: national politicians decided the aims of policy, government commissions of inquiry engaged experts who compiled available knowledge and initiated research projects. Parliament turned the resulting proposal into law, a civil service agency implemented the policy and local authorities put it into effect. During the $1950 \mathrm{~s}, 60 \mathrm{~s}$ and $70 \mathrm{~s}$ the pace of social reform was high. The strong state led the transformation of society and there was a sense that everything was moving forward.

However, in the last two or three decades, this rationalist political culture has changed. In 1990, a state committee stated that an end had come to strong public expansion, centralised bargaining based on a historical compromise between labour and capital, social engineering and centrally planned standard solutions (SOU 1990, p. 44). Demands for local influence, decentralisation and individual freedom of choice grew and the legitimacy of national administrative agencies declined.

The decline of the strong state included policy as well as institutional changes. Around 1990 there was an outburst of reforms of institutions for policy making, administration and implementation. The reformed institutions were not to implement political programmes but to disseminate information, to run contact programmes and to evaluate (Lindvall and Rothstein 2006). Education was one of the welfare areas most radically affected by the developments of the 1990s. It was directly influenced by economic cuts and demographic changes while, at the same time, the education system was restructured. The National Board of Education was replaced by the National Agency for Education constructed around evaluation and coordination efforts. 


\section{Comprehensification of the Swedish school system}

The implementation of the Swedish comprehensive school reforms between 1950 and 1971 would not probably have been possible if it had not been for the strong state based on consensus (Heidenheimer 1974). Up until the beginning of the 1950s, Swedish schools reflected the traditional European dualistic pattern. It was not until after World War Two that the School Commission proposed a comprehensive school reform. It was, after the war, possible to reach consensus about the fact that social goals were more important than purely pedagogical objectives. The value of mixing social groups in the same school was regarded as important, as well as the necessity of 'a vaccination against authoritarian belief systems'. There was also pressure for reform due to the overpopulation of the intermediate grammar schools.

In 1950, the Parliament took the decision to introduce a comprehensive school system-beginning with a ten-year experimental period. One of the aims of this experimental period was to try out and develop methods and ways of working that were appropriate for the comprehensive school. Another was to compare the results of traditional grammar schools with those of the non-selective comprehensive school. Although there was a lack of clear-cut results concerning the efficiency of the new comprehensive schools (Fältheim et al. 1959), a step-by-step policy of integrating parallel school types was pursued during the period 1950-1962.

Not only Social Democrats but also the Liberal and Centre political parties supported the school reform as a means of achieving social goals as well as economic growth. At no time did any Swedish political party take a clear-cut parliamentary stand against comprehensification. In 1962, the nine year comprehensive school legislation reached inter-party committee agreement (with a great deal of help from the Liberal Party leader Gunnar Helén).

The 9-year comprehensive school was divided in three stages ( 1 to 3, 4 to 6 and 7 to 9). The 9th year was, initially, differentiated based on the future study paths of the pupils. Since such a (self-selected) differentiation did not turn out well, it was abolished. However, the pupils could choose between general or special (more advanced) studies in languages and mathematics.

By the end of the 1960s an integration of the upper secondary school system had followed - integrating the vocational educational programmes into the upper secondary level. In 1971 a full comprehensification was carried out by the integration of the then three types of secondary schools into what was called 'gymnasieskolan' (upper secondary/high school approximately). In 1994 vocational programmes were prolonged with more theoretical studies in order to open up for the opportunity to continue to higher education. One primary aim was to avoid the construction of blind alleys. It should always be possible to continue education. One important part of this policy was municipal adult education facilities at secondary level.

The reform of teacher education followed. In order to provide the new comprehensive schools with teachers for forms 7 to 9 , elementary school teachers received further education. In 1954 a new, integrated, teacher education (at a teacher education college) was proposed. This was the first step in an integration of the elementary teacher seminar tradition with the secondary school teacher university tradition. These efforts to achieve 
integration (including the education of pre-school teachers) of the different teacher education traditions continued in the reforms of 1968, 1988 and 2001.

\subsection{Integration}

One overall concept in these reforms was integration in combination with individualisation. Before the comprehensive school reform, around $30 \%$ of each age group attended the intermediate grammar school, while after the reform almost $100 \%$ of each age group was expected to follow the same curriculum. The grammar school tradition was the prototype for forms 7 to 9 .

Different kinds of special classes for "pupils with problems" were established — apart from 'help-classes' for the less able, special classes for pupils with learning difficulties and also 'observation classes' for pupils with other problems were established. It was also possible for individual pupils to leave the class to get help from a special teacher. The special classes gradually disappeared and were replaced by a system of integrated special education, i.e. special teachers came to the classrooms to help those who needed extra help.

Integration concerned not only different school forms and classes but also school subjects, the school day (integrating formal schooling and leisure time activities), as well as home and school life. Pre-school was to be integrated in the school so that soft transitions between the school forms could be accomplished. The idea of 'one school for all children' unfolded around the concept of integration as well as 'sameness'. Equity was to be accomplished through sameness - between schools, subjects, pedagogical practices etc. Ability-grouping of pupils was not allowed. The only accepted grouping of the pupils was into 'general' and 'special' study tracks in mathematics and languages. During the 1980s, however, the space for individual choices in stage 7 to 9 expanded.

\subsection{Examination and marks}

Another important characteristic of the implementation of the comprehensive school was the elimination of the Abitur exam at the end of upper secondary school and a new system of awarding grades. The new system was a norm-referenced system-based on the idea that grades should be expected to be distributed in the same way as biological phenomena-i.e. in accordance with a Bell curve. With such a grading system, an idea of a certain amount of failures as 'normal' was established $(7 \%$ were expected to get the lowest grade, $24 \%$ next to lowest and so on). Standardised national tests were constructed according to the Bell curve and teachers were expected to adjust grades in accordance with the results of the tests.

Gradually criticism against this system grew. The distribution of grades did not easily follow the Bell curve. Incentives for pupils to make more effort diminished since the system was connected to an idea that only a certain number of the highest grades could be given. Even if the bell curve was not supposed to be applied in a single class but on a national level, it was often used on school level and sometimes even on class level.

Formal grades were gradually abandoned in the lower classes. Formal grades were not assigned until the later school years and from the mid 1990s only in forms 8 and 9. 


\subsection{Individualisation within the 'unified class'}

Teachers had to teach more mixed ability classes than before. Individualised teaching methods were recommended, i.e. individualisation was regarded as the way to accomplish differentiation within the unstreamed school. This was not, however, an easy task. The teachers were frustrated about 'teaching at the right level' as well as finding ways for individual work, where the 'fast' pupils would not be bored or restrained by the 'slow' pupils while at the same time they had to give the 'slow' pupils time enough to finish their work.

During the 1970s and 1980s, as a response to this dilemma, elementary school teachers generated ways of organising school work based on the single individual's work. As a result, a new teaching practice emerged. It was based on pupils' 'own work' in which they plan, monitor and evaluate their own school tasks (Carlgren et al. 2006).

This is a teaching practice that has redefined the roles of pupils as well as teachers (Eriksson 2009). Pupils are expected to take responsibility for their own learning while teachers are, to a great degree, turning into supporters and advisers. Their monitoring of pupils' work becomes more indirect.

\subsection{The growth of a centralised bureaucracy}

One aspect of the strong state was close connection between political actors, central bureaucrats and educational researchers. During the 1950s and 60s the central administration (the National School Board) expanded and the number of bureaucrat experts grew. Centrally developed standard solutions were to be disseminated in major implementation programmes. Solutions were legitimised by research.

Educational researchers were mobilised to provide arguments for political decisions regarding comprehensive school reforms. One important example was the calculations regarding the size of the 'reserve of abilities' within different social classes as well as the advantages of delaying the choices of young people about their future until later in life (Husén and Härnqvist 2000).

Concerning 'the inner work of schools' (i.e. ways of working and methods) the researchers could not produce such clear results as they could about the probable effects of the comprehensive school on a societal level. This did not, however, reduce the 'central belief' in the necessity to introduce certain ways of working. In spite of a lack of results, use of certain methods was strongly recommended by the central bureaucracy. Researchers were asked to describe and analyse the processes connected to the implementation of these methods (Carlgren 1986).

Social science researchers and bureaucrat reformers produced the theories, research artefacts and potential arguments with which the decision makers could defend their policies. They consequently restructured the perception of 'educational realities'. As a side effect they legitimised what can be called 'state progressivism' with an emphasis on 'the child in the centre', 'active methods' and giving pupils opportunities to actively 'search for knowledge'. Since research was so intertwined with policy development and implementation, it was almost impossible to distinguish political rhetoric from research-based statements. 


\subsection{The Swedish school reform and the teachers}

One implication of centralisation and 'the iron triangle' between researchers, policy-makers and central bureaucrats (Rosengren and Öhngren 1997) was the gradual marginalisation of teachers from school development. The elementary teachers' unions had been involved in the struggle to abolish the dualistic school system since the beginning of the century ${ }^{1}$ and quite a few teachers were also involved in development work and research. Progressive teachers from all Nordic countries met at summer courses and meetings for professional exchange and discussion. However, after the parliamentary decision of 1950 (regarding the introduction of the comprehensive system), these courses and meetings organised by teachers were gradually replaced by centrally planned courses (Carlgren 1986; Hermansson 1974). The main actors during the centrally planned courses were no longer teachers but educational researchers and central bureaucrats. Consequently, teachers lost ownership of their professional development.

From having been actors in school development, involved in research on teaching and professional development, teachers became consumers of research results (transformed into certain working methods) and into objects to be changed. Teachers were regarded as conservative and reform resistors. The perceived unwillingness to change among teachers was transformed into research projects. A similar detachment of teachers from research and development work can be noted in other countries which lean heavily on reform as the mechanism for changing schools (Stigler and Hiebart 1999; Zeichner and Noffke 2001).

However, during the 1980s, tendencies towards decentralisation, introduction of more choices for the pupils and a growing concern about reliance on central standard solutions to school problems paved the way for the return of a concept of professional teachers being responsible for locally adapted school development. After several decades of denial of teachers' knowledge — when teachers were regarded as problems rather than problem solvers - they were suddenly considered (from a central bureaucratic perspective) to be professionals with the ability to solve most problems. This drastic change-from a situation in which teachers were attributed almost no knowledge to a situation when they were considered to know everything necessary for school development-has been described as a shock-professionalisation (Carlgren and Klette 2008).

\section{Restructuring education in Sweden in the 1990s}

During the first half of the 1990s, not only new national curricula and a new grading system were introduced but also several other reforms including the introduction of a voucher system and the possibilities for establishing 'independent schools'. The voucher system opened up for market mechanisms and a competition orientation within the schools. The National Board was closed down and substituted with the National Agency for Education. While the National Board had focused on producing guidelines and recommendations for schools the National Agency was constructed around the idea of informative governance. 
By the end of the 1980s, after a teachers' strike, the employment of the teachers was transferred from the state to the municipalities. Yet another change of great importance was that in the middle of the 1990s a new teacher contract was negotiated introducing individual salaries and a link between teacher salary and involvement in school development.

The restructuring of education has been a world-wide movement with many similarities in different countries. ${ }^{2}$ However, Swedish education seems to have been restructured faster and more radically than most other countries - turning it into one of the most decentralised systems in the OECD (Lindblad et al. 2002).

The introduction of management by objectives and governing by results called for new kinds of governing documents (Carlgren 1995). The new National Curriculum opened up for local variation. The idea was that the actual content of teaching (the subject matter) may vary according to local and individual circumstances - as long as certain qualities of knowledge (formulated in the National Curriculum and syllabuses) are developed. Although the total number of teaching hours in each subject was decided at national level, local schools can decide about the distribution of time over the nine years of study. The teachers were no longer expected to adopt centrally developed standard solutions but to develop their own solutions based on their professional knowledge.

The grading system was also reformed-from a norm-referenced to a knowledge-referenced system. This change was connected to the ambitious teaching aim that everyone should leave the 9 year compulsory school with a passing grade.

Parallel to all these changes was a change in vocabulary: Expressions such as 'equality of opportunity', 'equivalent standards', 'a school for all children', 'no blind educational alleys' faded and were gradually replaced by concepts including 'excellence', 'competition', 'free choice' and 'quality'.

This discursive change is also a global phenomenon. Neo-liberal ways of thinking got a hold on much of the restructuring rhetoric and led to an economisation of the language of schooling (Lindblad and Popkewitz 2000). While some researchers have emphasised the professionalisation aspects of the restructuring reforms, others argue that accountability, competitiveness and performativity (targets as well as standards) will lead to deprofessionalisation of teachers, who will be oriented towards performance indicators while education loses its social meaning and becomes commoditised.

The restructuring reform of the end of the 20th century have been regarded as "part and parcel of transitions to late modernity" (Lindblad and Popkewitz 1999, p. 5) and is an aspect of the so-called audit society. Carnoy and MacDonell (1990) state that: "Restructuring is a governance or management reform" (p. 51). It is neither about centralisation nor about decentralisation as such, but about what should be decided on the different levels.

The audit society has two faces. One is autonomy and self-regulation (and decentralisation) - the other is about control and standardisation (centralisation). In Sweden the first phase of restructuring emphasised the decentralising aspects in the construction of large spaces for local decisions. The municipalities, the schools and the teachers were seen as self-regulating systems. The rhetoric leaned heavily on the idea of professional teachers developing solutions grounded in their professional knowledge base. Lately more and more emphasis has been placed on the centralising aspects of the reforms. 


\section{Trends in restructured Swedish schools}

The restructuring of the Swedish educational system during the 1990s has radically changed the landscape of education. Decentralisation and transfer of responsibility to the municipalities has created incalculable local variations and put the schools under double pressure. The National Curriculum and the municipality school plans sometimes contradict each other.

At the same time, when the municipalities became employers, a system of individual salaries was introduced. In local negotiations it appears that the pre-school teachers have come out better than the upper secondary school teachers, which is one aspect of growing tension between the two teachers' unions. ${ }^{3}$

A few examples are provided below of the trends that will probably be important for the future development of the Swedish school system.

\subsection{The new grading system and new demands on teachers to accomplish learning}

In a Nordic comparative project (Klette et al. 2000), Swedish teachers - in contrast to their colleagues in Denmark, Finland and Norway_asserted that the reforms of the 1990s had put pressure on them to actually accomplish learning (as distinguished from teaching). The change from a norm-referenced to a knowledge and criterion-referenced grading system (connected to three different grades: pass, pass with distinction, pass with high distinction) have been reported to have deep implications for schools and teachers' work (Eriksson 2007). With the norm-referenced system it was accepted that $31 \%$ were awarded the two lowest grades, but with the new system it has been taken for grantedalmost without any discussion - that everyone should get a pass.

Up to now, 11 to $12 \%$ of an age-group do not qualify for further studies in the upper secondary school i.e. they do not reach a pass in Swedish, Mathematics and English. Among these are quite a few immigrant children who take 'Swedish as a second language' with a $23 \%$ failure figure. Around $20 \%$ to $25 \%$ have failed in at least one of these subjects when leaving the 9-year comprehensive school. This is - in the public debate-considered to be a failure and the sign of a decline of the Swedish school. There has, however, never been a situation in Sweden when $100 \%$ of an age group passed the 9 year comprehensive school in that sense. Nevertheless, the new demands seem to make the teachers put much of their efforts into helping all their pupils to pass.

\subsection{Independent schools}

The growth of independent schools has definitely changed the Swedish educational landscape. In the beginning of the 1990 s, $99 \%$ of the school population went to public sector schools, while today around $10 \%$ are enrolled in independent schools. The number of applications to start independent schools continues to rise. Since 2000 most of the new independent schools belong to large-scale, commercial school company groups. Buying and selling schools have become a profitable business and lately this market has crossed country borders. 
Today around $12 \%$ of the compulsory schools (up to year 9 ) and about half of the upper secondary schools are independent. This change has strongly affected the situation for the public sector schools. The municipalities are experiencing difficulty in gaining control of their school budgets and schools in underprivileged areas lose their good students (Lindgren 2005).

\subsection{Individualisation and self-regulated learning}

There has been a remarkable increase in the individual working teaching form in Swedish schools between 1995 and 2000 (Carlgren et al. 2006). Granström (2003) compares the percentage of different teaching forms in Swedish comprehensive classrooms from 1960, 1980 and 2000:

$\begin{array}{llll} & \text { Class teaching } & \text { Group work } & \text { Individual work } \\ 1960 & \mathbf{6 0} \% & \mathbf{1 8} \% & \mathbf{2 2} \% \\ 1980 & \mathbf{5 0} \% & \mathbf{2 4} \% & \mathbf{2 6} \% \\ \mathbf{2 0 0 0} & \mathbf{4 5} \% & \mathbf{1 2} \% & \mathbf{4 1} \%\end{array}$

While individual work has almost doubled, class teaching as well as group work has decreased. There are also studies showing that an increasing amount of class teaching time is used for instructions for individual work (Lindblad and Sahlström 2001). In yet another study students have been asked to estimate the share of their individual/own work. The study shows that individual work has changed from $25 \%$ in 1992 to $50 \%$ in 2003 , while the corresponding figures for teacher-led class teaching is $43 \%$ (1992) and $28 \%$ (Skolverket 2003)

The combination of the new grading system (based on national as well as local criteria) and the abolishment of courses and traditional syllabuses in combination with a decree in the National Curriculum that the pupils must be afforded the possibility to take responsibility for their own learning has, I believe, accelerated the expansion of individual work. As a consequence teachers do not teach very much - especially not in the lower grades. The pupils are therefore thrown upon their own resources for success to a much greater extent than before.

\subsection{Individualised streaming and backwards pedagogy}

One noticeable trend is the introduction of individualised grade-related tracks. The pupils choose a 'track' depending on what grade they are aiming for. The three different grade tracks are quite different in terms of content. It is not possible to talk about equally good education for all since the 'pass-track' is oriented towards facts and lower-order thinking while the more qualified knowledge is restricted to the other two tracks. Let me add that it was shown in an analysis of the TIMSS results that Swedish pupils now perform extremely well (actually best in the world) in very simple tasks - i.e. the kind of tasks that make up the pass-track (Skolverket 2007).

The erosion of class teaching and the growth of individual work have, together with the concept that the criteria for assessment should be given to the students beforehand, paved 
the way for what can be called 'backwards pedagogy'. Rather than regarding teaching as something coming before assessment, the students are given not only the objectives for their learning but also the criteria by which they will be assessed. This brings the risk that they will focus on these criteria only, i.e. that they will learn the criteria for assessment rather than what is to be assessed.

\subsection{Declining achievement}

National evaluations, as well as international achievement tests, show that there is a decline in results - especially in mathematics and science. Sweden has always been very successful in reading literacy (and still is) — but also in this area a decline is obvious. In a study concerning achievement in international tests between 1965 and 2006 Jan-Eric Gustafsson (2009) draws the conclusion that Swedish pupils were achieving very well up to the first half of the 1990s. After that and especially after 2000 a decline can be noticed.

It seems obvious that the restructured school is under-achieving, although factors outside of the school world, such as the severe economic cuts of the 1990s and waves of immigration, have to be taken into account before drawing far-reaching conclusions.

\subsection{Growing segregation}

According to Lindgren (2005) declining achievements can, to a large extent, be explained by growing achievement gaps related to pupils' socio-economic backgrounds. Among those who fail in one or more subjects in grade 9, children with non-Swedish backgrounds, or with parents with a poor educational background, are over-represented.

According to Lindblad et al. 2002 differences between schools, areas and regions are on the increase. During the economic recession of the 1990s, public expenditure on childcare decreased markedly and in ways that tended to hit the children most in need of support.

\subsection{The new nostalgic politics of education — divide and separate}

After a successful election campaign, a four-party alliance, formed by the 'new' Conservatives together with the Liberal, Centre and Christian Democratic parties, came into power in 2006. The culturally conservative Liberal Party has dominated educational policy-making, carried out a number of reforms and succeeded in setting the agenda in the public debate on schooling. This agenda-setting began during the 1990s and has grown into what seems to be new hegemonic thinking about education. Almost all political parties are accepting the new language of schooling. To a large extent it has been built around criticism of the former, social democratic school ideology (which is described as giving social goals priority over pedagogical goals, not demanding enough from the pupils and accepting the development of social chaos in the schools). The 'vision' in the new educational rhetoric is about re-establishing a school characterised by 'peace and quiet' with a focus on knowledge acquisition and with teachers accepted as authorities. It aims at a 
re-establishment of different pathways in the schools leading to different careers out of school.

Although the comprehensive school system as such has not (yet) been questioned, the vision is, from my point of view, a nostalgic retrospect. It is a break with the 20th century idea of school as a spearhead of progression towards the future. Today's 'vision' is not directed at the future, but rather to the re-establishment of the school that once was.

The point of departure for the 'new' politics of education is some alleged 'truths' about school such as:

- Swedish pupils learn less than pupils in other countries,

- Swedish classrooms are the most chaotic in the world,

- $25 \%$ of pupils drop out of upper secondary school (which is the worst in the world),

- the aim of providing too many pupils with higher education creates unemployment,

- Swedish pupils study less than the rest of the world (they do less homework, they spend fewer days in school, and have fewer hours of teaching) (10 sanningar om skolan, Folkpartiet, Liberalerna 2006).

Before the election, the Liberal Party promised to restore a school of knowledge and they are now realising this plan. A number of reforms have been forcefully launched since 2006. The plan includes elements, such as grading at an earlier age than today, re-establishing peace and quiet in the schools by re-introducing a 'behaviour' grade, restoring the authority of teachers by giving them tools (e.g. confiscating cell phones and other disturbing equipment), re-differentiating the upper secondary school, re-introducing apprenticeship vocational training, re-differentiating teacher education and so on.

Although there have been several attempts to challenge the new hegemony, these have not been very successful. Also opposition political parties have basically accepted many of the conservative/liberal 'truths' about the Swedish school.

\section{Conclusions}

The decline of achievement of the Swedish pupils in international tests coincides with the emergence of the restructured Swedish school system: the new National Curriculum, the new grading system, the growth of pupils' individual work and erosion of class teaching as well as the growth of controlling measures. Even if there is an obvious risk in drawing too far-reaching conclusions from this coincidence, it should at least be reflected on.

A similar tendency for growth of individual work as well as declining results (in e.g. TIMSS) (as in Sweden) can be noticed in Norway. Norway, and especially Sweden, are the two countries using the largest amount of time for individual work in mathematics, and they show similar trend as far as results are concerned (Bergem 2008). In Finland, however, with more traditional teaching practices, such decline can not be noticed. Finnish comprehensive school reform was introduced a bit later than in Sweden, during the 1970s, and support for this form of school is still very strong among its citizens. The social position and the prestige of Finnish teachers have been, and still are, comparatively high and Finland seems to be the only Nordic country that does not have problems in attracting students to teacher education. It has also been shown that Finnish teachers are 
more autonomous than their colleagues in, for example, Sweden (Lindblad and Popkewitz 2001).

Today, Finland is the star of the Nordic countries and everyone wants to follow. However, there are some important differences that must be considered: Finland has had almost no immigration in comparison to Sweden, and it is a more traditional society where the pupils' respect for teachers, according to Simola (2005, p. $465 \mathrm{f}$.), is supported by an authoritarian eastern culture accompanied by a mentality of obedience. From my point of view, one important aspect of the explanation of the differences between the Nordic country school systems is that surrounding cultures are mirrored in pedagogical practices. The growth of individual work in Sweden and Norway can thus be regarded as a response to a social situation that teachers have to deal with. It is a response to what teachers themselves often describe as 'a new kind of youth', i.e. pupils who seem to have incorporated the concept of self-regulation and of being masters of their own fates. The relationship between ways of organising and carrying out school work and surrounding cultural aspects is often neglected in comparative discussions and analyses. It is, for example, worth considering whether the horizontal (non-authoritative) relationships between Swedish teachers and students are possible to change into vertical authoritarian relationships. Hence, instead of turning the clock back, the challenge is to raise the quality of teaching in accordance with modernisation processes outside of schools — which in all probability will continue.

The Swedish 'new' nostalgic educational policies are based on scandalising yesterday's comprehensive school rather than the underachieving restructured school of today. Consequently, these new policies are not able to analyse the problems nor to come up with good solutions concerning this restructured school. It is trapped within the performative paradigm - matching every new problem with more control stations. However, as expressed in a Swedish saying: "The pig doesn't get any fatter by being measured or weighed". Since the new 'nostalgic' policy offers no ideas for making things better-except more control and inspections - there is an obvious risk that the achievement decline will continue and so will the growth of segregation. What appears to be needed in Sweden today is development and improvement of teaching - something which is not included in the present policy paradigm.

The future of teaching is related to the future of teachers. Although there seems to be a consensus today that 'teachers matter' - accompanied by rhetoric concerning raising the status of the teaching profession - the present policy paradigm does not include measures for creating space and resources for teachers to develop the quality of teaching. Rather than promoting teaching as a profession, today's policy strengthens the change of teachers into what Castells call 'flexible knowledge workers' (Castells 1998).

To bring my argument to an end, the question about how the high-achieving Swedish school system could be transformed into an underachieving system must be attended to. It may seem paradoxical that the Swedish school system achieved as well as it did before the 1990s, considering the fact that issues of knowledge were so under-emphasised to the benefit of social issues, such as integration and democratic education. From my perspective the increase in individual work, together with a strong emphasis on the pupil's responsibility for his/her own learning, has led to an erosion of the unstreamed, unified class teaching which characterised the previous comprehensive school. A new differentia- 
tion within the comprehensive school has been established in which a considerable proportion of the pupils by their self-selection of the lowest track exclude themselves from more advanced knowledge tracks.

The situation may also be related to the increase of independent schools which, on the one hand, has attracted the best students and thus created a heavier load for the municipal schools and, on the other, has financially drained the school system. Taking into consideration the financial problems of the 1990s, the effect of this should not be neglected.

The restructuring of the Swedish school system at the beginning of the 1990s was extremely radical - a strongly centralised system was replaced by a strongly decentralised system, while at the same time the pressure to perform increased. Much of what previously had been decided on a central level was now left to teachers and pupils to decide (and negotiate). Consequently the school system was destabilised and more open to outside influences - influences impregnated with neo-liberal ideas of choice, competition and everyone's responsibility for his/her own life.

So, what will happen to the Swedish comprehensive school system? The system as such has not been questioned (yet). It does not seem to be necessary since it appears to be possible to develop a highly selective system within the existing school system. However, somehow its comprehensiveness has been lost in the restructured transition of the school during the 1990s.

Open Access Dieser Artikel unterliegt den Bedingungen der Creative Commons Attribution Noncommercial License. Dadurch sind die nichtkommerzielle Nutzung, Verteilung und Reproduktion erlaubt, sofern der/die Originalautor/en und die Quelle angegeben sind.

\section{Endnotes}

1 In contrast to the grammar school teachers' union.

2 Above all, it refers to new governance measures among them quasi-markets, public-private partnerships and evaluations, often connected to state legislation, control and new forms of bureaucracy.

3 Lärarförbundet organises mainly primary school and pre-school teachers and Lärarnas Riksförbund mainly secondary school teachers.

\section{References}

Bergem, O. K. (2008). Individuella vs kollektiva arbeids/former. PhD-avhandling. Oslo: Oslo Universitet.

Carlgren, I. (1986). Lokalt utvecklingsarbete (Acta Universitatis Gothoburgensis). Göteborg: Göteborg Universitet.

Carlgren, I. (1995). National Curriculum as social compromise or discursive politics? Some reflections on a curriculum-making process. Journal of Curriculum Studies, 27, 411-430.

Carlgren, I., \& Klette, K. (2008). Reconstructions of Nordic teachers: Reform policies and teachers' work during the 1990s. Scandinavian Journal of Educational Research, 52(2), 117-133. 
Carlgren, I., Klette, K., Myrdal, S., Schnack, K., \& Simola, H. (2006). The individualisation of teaching. Scandinavian Journal of Educational Research, 50, 301-326.

Carnoy, M., \& MacDonell, J. (1990). School district restructuring in Santa Fe, New Mexico (CPRS Report Series RR017). Rutgers, NJ: Eagleton Institute of Politics, State University of New Jersey.

Castells, M. (1998). The information age: Economy, society, and culture (vol. III: end of millennium, 2nd ed. 2000). Oxford: Blackwell.

Donnelly, K. (2005). Benchmarking australian primary school curricula. Canberra: Australian Government, Department of Education, Science and Training. http://www.dest.gov.au/NR/ rdonlyres/B6E3D22B-6E60-4A1F-920A-EFAB3E5C45FA/7940/benchmarking_curricula_ report2.pdf. Accessed 12 Oct 2009.

Eriksson, I. (2007). Contemporary changes in teaching and instruction in Sweden - changes in actions or the emerging of a new activity. Paper presented at the FISCAR conference, 27-28 Sep 2007 in Helsinki, Finland.

Eriksson, I. (2009). Re-interpreting teaching: A divided task in self-regulated teaching practices. Scandinavian Journal for Educational Research, 53(1), 53-70.

Fältheim, Å., Husén, T., \& Marklund, S. (1959). Försöksverksamhet med 9-årig enhetsskola. Sammanfattande redogörelse för läsåren 1949/50-1958/59 (Kungliga Skolöverstyrelsens skriftserie, 42). Stackholm: Royal National Board of Education.

Folkpartiet Liberalerna. (2006). 10 sanningar om skolan. PM från folkpartiet liberalerna. http://www. folkpartiet.se/ImageVault/Images/id3608/ImageVaultHandler.aspx. Accessed 12 Oct 2009.

Freeman, R., Swedenborg, B., \& Topel, R. (2006). Reforming the welfare state: Recovery and beyond in Sweden. http://www.sns.se/document/nber2_utdrag_eng.pdf. Accessed 12 Oct 2009.

Granström, K. (2003). Arbetsformer och dynamik i klassrummet [Teaching forms and dynamics in the classrooms] I. S. Selander (Ed.), Kobran, nallen och majjen (pp. 223-243). Stockholm: Myndigheten för skolutveckling.

Gustafsson, J.-E. (2009). Kunskaper och färdigheter i grundskolan under 40 år: En kritisk granskning av resultat från internationella jämförande studier. Göteborg: Göteborg Universitet.

Heidenheimer, A. (1974). Comprehensivisation attempts in Sweden and West Germany. Comparative Education Review, 18, 388-410.

Hermansson, E. (1974). Upplevelser och påverkan: Jämförelsematerial för pedagogiskt intresserade. Stockholm: Sveriges lärarförbund.

Husén, T., \& Härnqvist, K. (2000). Begåvningsreserven: En återblick på ett halvsekels forskning och debatt. Uppsala: Föreningen för svensk undervisningshistoria.

Klette, K., Carlgren, I., Rasmussen, J., Simola, H., \& Sundqvist, M. (2000). Reform policy and teacher professionalism in different Nordic countries (Report No.10/2000). Oslo: Oslo University, Institute of Educational Research.

Lindblad, S., \& Lundahl, L. (1999). Education for a re- or de-construction of the 'strong society'? In S. Lindblad \& T. S. Popkewitz (Eds.), Education governance and social integration and exclusion: National cases of educational systems and recent reforms (Uppsala Reports on Education 34, pp. 204-222). Uppsala: Univ. Press.

Lindblad, S., Lundahl, L., Lindgren, J., \& Zackari, G. (2002). "Educating for the New Sweden?" Scandinavian Journal of Educational Research, 46, 283-303.

Lindblad, S., \& Popkewitz, T. S. (Eds.). (1999). Education governance and social integration and exclusion: National cases of educational systems and recent reforms (Uppsala Reports on Education 34). Uppsala: Univ. Press.

Lindblad, S., \& Popkewitz, T. (Eds.). (2000). Public discourses on education governance and social integration and exclusion: Analysis of policy texts in European contexts (Uppsala reports on Education, 36). Uppsala: Uppsala University, Department of Education.

Lindblad, S., \& Popkewitz, T. (2001). Listening to education actors on governance and social integration and exclusion. A report from the EGSIE Project. Uppsala: Uppsala University, Department of Education. 
Lindblad, S., \& Sahlström, F. (2001). Interaktion i pedagogiska sammanhang [Interaction in pedagogical contexts]. Stockholm: Liber.

Lindbom, A., \& Rothstein, B. (2004). The mysterious survival of the Swedish welfare state. Paper presented at the American Political Science Association, September 2nd-5th in Chicago. Panel 14-3: The Survival of the Scandinavian Welfare State Model.

Lindgren, A.-M. (2005). Flum? Nej, segregation - en rapport om skolans tyngsta problem (Rapport nr 8). Stockholm: Tankesmedjan Idé \& Tendens.

Lindvall, J., \& Rothstein, B. (2006). Sweden: The fall of the strong state. Scandinavian Political Studies, 29, 47-63.

Rosengren, K.-E., \& Öhngren, B. (Eds.) (1997). An evaluation of Swedish research in education. Uppsala: HSFR, Swedish Council for Research in the Humanities and Social Sciences.

Ruth, A. (1984). The second new nation: The mythology of modern Sweden. Daedalus, 113(2), 53-96.

Simola, H. (2005). The Finnish miracle of PISA: Historical and sociological remarks on teaching and teacher education. Comparatice Education, 41(4), 455-470.

Skolverket. (2003). Nationella utvärderingar av grundskolan 2003 (NU03). Stockholm: Fritzes kundservice.

Skolverket. (2007). Svenska elevers matematikkunskaper i TIMSS 2007. Stockholm: Fritzes kundservice. http://www.skolverket.se/content/1/c6/01/70/65/Svenska\%20elevers\%20kunskaper\% 20i\%20TIMSS\%202007.pdf. Accessed 12 Oct 2009.

SOU. (1990) Demokrati och makt i Sverige (1990:44). Stockholm: Allmänna förlaget.

Steiner-Khamsi, G. (2003). The politics of league tables. http://www.sowi-online.de/journal/20031/tables_khamsi.htm Accessed 12 Oct 2009.

Stigler, J., \& Hiebart, J. (1999). The teaching gap - Best ideas from the world's teachers for improving education in the classroom. New York: Free Press.

Zeichner, K., \& Noffke, S. (2001). Practitioner research. In V. Richardson (Ed.), Handbook on research on teaching (4th ed., pp. 298-330). New York: MacMillan. 